\title{
Analisis Penerapan Manajemen Resiko Covid-19 Pada Industri Perhotelan (Studi kasus Pada Abadi hotel Sarolangun)
}

\author{
${ }^{1}$ Novelia Aliyah Pitri, ${ }^{2}$ Kasful Anwar US \\ ${ }^{12}$ Jurusan Ekonomi Syariah, Fakultas Ekonomi dan Bisnis Islam, Universitas Islam Negeri Sulthan Thaha \\ Saifuddin Jambi
}

Article history

Received: 12-03-2021

Revised: 10-04-2021

Accepted: 30-05-2021

*Corresponding Author: Novelia Aliyah Pitri, niversitas Islam Negeri Sultan Thaha Saifuddin Jambi

Email:

Noveliaaliyahpitri14292@g mail.com

\begin{abstract}
Abstrak: Pandemi global yang terjadi pada awal tahun 2020 telah mengubah industri parawisata secara menyeluru. Hal ini telah memberikan dampak yang menejutkan pada sector-sector global,terutama retail,parawisata dan perhotelan. Dengan adanya PSBB (pembatasan Sosial Berskala Besar), serta banyaknya perjalanan udara yang ditutup membuat industri parawisata mengalami penutupan serta pengurangan siknifikan dari marketnya. Keadaan ini menyebabkan suatu pandemi yang disebut depresi parawisata terhadap bebrapa penyebab dari bencana pristiwa, seperti bencana alam (gempa bumi,stunami,banjir dan kebakaran hutan) sebab sebab politik ( perang,eleksi,demonstasi0) sebab-sebab ekonomi (turunnya Pasar modal, resesi ekonomi)dan penerapan protoko, kesehatan pada hotel merupakan salah satu cara didalam mempertahankan loyality konsumen. Pengumpulan data,reduksi data, penyajian data,penarikan kesimpulan dan verifikasi dilakukan dengan metode observasi dari sumber sumber internet tertentu. Berdasarkan hasil penelitian dan pembahasan covid-19 menghantam indonesia pada umumnya terdampak terhadap Operasional perhotelan.

Kata Kunci : industriperhotel, Pendapatan,kebijakan pemerintah,Implikasi covid-19
\end{abstract}

\section{PENDAHULUAN}

Menurut World Health Organiztion (WHO) corona virus merupakan virus yang menginflikasi sistem pernapasan. Infeksi virus ini desebut covid-19.virus ini menyerang sistem pernapasan pada manusia. Dimana pada awal tahun 2020 tepatnya pada bulan maret vitus ini mewabah hampir diseluruh dunia. Pneumonia akut,sampai pada kematian bagi penderitanya. Pandemi ini bermula pada negeri china yaitu kota wuhan pada akhir 2019 dan melanda seluruh negara yang ada didunia termasuk indonesia.

Di indonesia sendiri penderita penderita covid-19 mulai ditemukan awal maret 2020 dimana sampai dengan april 2020 telah terkompirmasi 2.956 kasus positif covid-19 dimana 250 kasus diantaranya meninggal dunia san 222 kasus sembuh dinyatakan sembuh. Penderita covid19 ini sudah tersebar hampir di 32 provinsi dari total 34 propinsi yang ada di indonesia. (https;//id.wikipedia.org/wiki/pandemi_kor onavirus_di_indonesia)

Dengan adanya pandemi ini tentunya tidak hanya memberikan dampak pada kesehatan saja tetapi juga kepada perekonomian di indonesia. Dampak covid-19 sangatlah besar dimana virus ini menyebabkan kelumpuhan perekonomian indonesua secara menyeluru terlebih untuk sektor pariwisata. Dikutip dari CCNIndonesia, menteri keuangan republik indonesia mengatakan bahwa proyeksi pertumbuhan ekonomi indonesia tidak akan melebihi 2,3\%. Bahkan, didalam industri terburuk, ekonomi indonesia bisa menus hinga $0,4 \%$ hal ini kan berdampak langsung terhadap perekonomian indonesia terutama tingkat inflasinya.penyebab dari hal ini diantaranya adalah turunnya kosumsi dan investasi yang dilakukan olah masyarakat dan juga pemerintah saat pendemi covid19. 
Dikutip dari CCN Indonesia, ketua umum PHRI yang menyatakan bahwa industri parawisata khususnya di indonesia sudah menjadi salah satu sektor yang menjanjikan dalam peningkatan taraf hidup masyarakat,dimana sektor sektor parawisata menjadi sektor yang menjanjikan bagi peningkatan perekonomian diindonesia. Karena banyak memiliki keungulan serta menjadi salah satu penyumbang peningkatan ekonomi terbesar untuk indonesia termasuk devisa bagi negara.

Adanya pandemi covid-19 yang membuat penurunan drastis terhadap jumlah kunjungan wisatawan lokal maupun mancanegara, hal ini menyebabkan beberapa hotel sepi pengunjung. Sejak diberlakukan kebijakan terkait social destancing dan phisycal distancing oleh pemerintah pusat maupun daerah hotel tersebut mengalami sepi pengunjung. Beberapa hotel mengambil kebijakan untuk menutup sementara dan merumahkan karyawannya,keputusan sulit ini diambil oleh manajemen hotel demi dapat bertaham dimasa pandemi ini.

\section{Rumusan Masalah}

1. Bagai mana impikasi covid-19 terhadap pendapatan abadi hotel

2. Bagaimana upaya yang dilakukan oleh manajemen hotel abadi hotel untuk bangkit dari keterpurukan akibat pandemi covid-19

\section{METODE PENELITIAN}

Penelitian ini merupakanpenelitiian kualitatif studi kasus yang mengkaji imfliksi covid-19 terhadap pendaptan perhotelah.penelitian studi kasus merupakan strategi yang lebih cocok bila pokok pertanyaannya berkenan dengan pencarian penyebab seperti "bagaimana" atau "mengapa" (karena penelitian ini hanya mengambil dari sumber internet maka peneliti tidak menuliskan studi kasus hotel mana yang diteliti) studi kasus sering digunakan secara luas dalam penelitian ilmu-ilmu sosial baik padaa displindisiplin tradisional (psikologi,sosiologi, ilmu politik dan antropologi) yang berkaitan dengan perencanaan dan pengembangan kawasan/wilayah, kebijakan dan ilmu manajemen.

\section{Desein penelitian}

Desein penelitian yang digunakan dalam penelitian ini adalah studi kasus tunggal karena hanya akan mengkaji tentang implikasi covi-19 terhadap pendapatan hotel.

\section{Kasus}

Pemilihan kasus didasarkan pada pemilihan secara purposive yaitu dipilih dengan pertimbangan dan tujuan tertentu. Dipilihnya kasus ini karena banyaknya informasi yang beredar terkait pendapatan hotel yang hampir secara keseluruhan mengalami penurunan dalam hal pendapatan hotel baik dari sisi penyewaan kamr, restauran dan segalan fasilitas hotel yang mendatangkan pendapatan bagi hotel. Informan

Dalam penelitian kualitatif penelitian adalah instrumen utama, sedangkan informan kunci (key informan) boleh peneliti sendiri atau orang lain yang dapat memberikan informasi mendalam tentang masalah yang diteliti. Adapun key informan dalam penelitian ini adalah General Manajemen Abadi Hotel, Marketing Manajemen dan Public Relation serta Accounting Manajer. Penemuan kay informan ini dipilih berdasarkan pengetahuan dan keterlibatan manajeman dalam hal operasional Abadi Hotel.

\section{Teknik Pengumpulan Data}

Teknik pengumpulan data yang digunakan dalam penelitian ini meliputi;

Observasi lapangan, yaitu pengumpulan data dengan mengamati proses kegiatan yang ada dihotel tersebut.

Wawancara mendalam (indepth Interview) yaitu pengumpulan data dengan melakukan wawancara mendalam terhadap informan kunci. 
Dokumentasi yaitu pengumpulan data yang berasal dari sumber sekunder berupa dokumendokumen yang terkait dengan penelitian ini.

\section{Analisis data}

Uji validitas data delakukan dengan teknik triangulasi data. Analisis data mengunakan teknik analisis data interaktif dengan tahapan yang meliputi pengumpulan data reduksi data,reduksi data, penyajian data, penarikan kesimpulan dan verifikasi. Untuk tahapan prosedur penelitian ini dimulai dari persiapan, pengumpulan data, analisis data dan penyusunan laporan penelitian.

\section{HASIL DAN PEMBAHASAN}

Salah satu hotel di indonesia merupakan hotel kelas melati yang berdiri di atea tanah selua 40 are. Hotel mulai beroperasi sejak tahun 2016 ,memiliki 1 fasilitas kamar yang terdiri dari 8 unit kamar dengan single bad dan 4 kamar double bad dengan tarif Rp. 350.000,- dan Rp. 450.000,-.dimana seriap kamar dipasilitasi dengan lemari,kamar mandi,closed duduk,water hitter, kursi serta televisi. Disamping iti juga Abadi Hotel memiliki Restourant Sekaligus menjadi Room Meeting bagi para tamu yang membutuhkan,

Data primer data yang dianalisis merupakan hasil observasi peneliti yang dilakukan pada Abadi Hotel. Dimana data primer tersebut merupkan hasil wawancara peneliti dengan key informan yang terdapat pada Abadi Hotel yang tertentu memiliki kompetensi dalam penyampaian informasi terkait dengan penelitian ini. Adapun key informan yang dihadirkan dalam penelitian ini adalah:

1. Fendi yunus rahman Sebagai general manajer Abadi hotel

2. Affan gafar Sebagai Marketing

3. Manajer and Public relation dan

4. Dwi efri reza Sebagai accounting Manajer

5. Data Sekunder

Data sekunder merupakan data-data bersumber dari laporan-laporan atau dokumen yang terkait. Diaman sata tersebut penulis dapatkan dari laporan keuangan yang diperoleh dari manajemen Abadi Hotel. Adapun data sekunder yang dapat disajikan pada penelitian ini merupakan data sewa kamar dan total pendapatan dalam rentang waktu enam bulan sebelum pandemi covid-19 dan enam bulan saat pandemic melanda dunia.

\section{Tingkat Hunian Abadi Hotel sebelum pandemi virus covid-19}

Data sekunder yang disajikan penulis tingkat hunian kamar abadi hotel sebelum covid 19 tepatnya periode 2019 sampai maret 2020.

\begin{tabular}{cccc} 
Tabel .2 tingkat hunian kamar dan pendapatan sebelum pandemi \\
\cline { 3 - 4 } NO & BULAN & $\begin{array}{c}\text { ROOM } \\
\text { SOLD }\end{array}$ & PENDAPATAN \\
\hline 1 & Oktober & 50 & Rp. 14,950.000 \\
2 & November & 41 & Rp.14,350.000 \\
3 & Desember & 144 & Rp. 48,675.000 \\
4 & Januari & 59 & Rp. 19.200.000 \\
5 & Februari & 56 & Rp. 19.200.000 \\
6 & Maret & 15 & Rp. 4.575.000 \\
\hline total & & 365 & Rp. 101.750.000 \\
\hline
\end{tabular}

Sumber data: abadi hotel

Dari data tersebut terlihat bahwa dalam rentang waaktu antara bulan oktober 2019 sampai dengan maret 2020 jumlah kamar yang terjual sebanyak 365 kamar dengan total 
pendapatan sebanyak Rp.101.750.000

\section{Tingkat Hunian Abadi Hotel saat pandemi virus covid-19 berlangsung}

Data sekunder kedua yang penulis sajikan pada penelitian ini adalah tingkat hunian abadi hotel saat pandemi virus covid-19 tepatnya periode aprip sampai dengan september 2020

\begin{tabular}{cccc}
\multicolumn{4}{c}{ Tabel 2 tingkat hunian kamar dan pendapatan saat pandemi } \\
\hline NO & BULAN & $\begin{array}{c}\text { ROOM } \\
\text { SOLD }\end{array}$ & PENDAPATAN \\
\hline 1 & April & 0 & Rp. 0 \\
2 & Mei & 0 & Rp.0 \\
3 & juni & 50 & Rp.17.500.000 \\
4 & juli & 60 & Rp.21.000.000 \\
5 & Agustus & 61 & Rp.21.350.000 \\
6 & September & 72 & Rp.22.450.000 \\
\hline \multicolumn{7}{c}{ TOTAL } & 243 & RP.82.300.000
\end{tabular}

Sumber data: abadi hotel

Dari data di atas terlihat bahwa dalam rentang waktu antara april sampai dengan september 2020 jumlah kamar yang terjual sejumlah 243 kamar dengan total pendapatan sebesar Rp. 82.300.000, dimana pada bulan april sampai dengan mei terjadi kekososngan hunian kamar yang diakibatkan pemberlakuannya lock down untuk wilayah sembalun dari pendatang luar.

Berdasarkan hasil observasi yang dilakukan oleh peneliti terhadap Rinjani Hill Hotel untuk melihat seberapa besar covid-19 dalam mempengaruhi tingkat pendapatan hotel diperoleh hasil bahwa covid-19 tidak berpengaruh signifikan terhadap pendapatan hotel dimana tingkat hunian kamar terlihat hanya beberapa kamar saja yang tidak ada pengunjungnya. Hal ini yang menjadi indikasi peneliti menyatakan bahwa covid-19 tidak terlalu berdampak terhadap pendapatan Sembalun Abadi Hotel jika dilihat dari sisi hunian kamar. Disamping itu juga restaurant dan meeting room yang menjadi salah satu fasilitas hotel juga tidak terlalu sepi dimana dari hasil pengamatan melalui observasi lapangan peneliti melihat terdapat beberapa tamu yang silih berganti memasuki restaurant dari Abadi hotel. Hal ini juga senada dengan hasil wawancara peneliti dengan GM Abadi Hotel Bapak Lalu yang menyatakan bahwa "pendapatan hotel dari sisi hunian kamar dan restaurant sejak dihentikannya WFH tidak mengalami penurunan yang berarti hanya saja saat diberlakukannya WFH dan sempat disolasikan wilayah Sembalun dari pendatang luar pada saat itu terjadi penurunan kunjungan hotel yang sangat tajam bahkan mencapai $100 \%$ selama 3 bulan berjalan akan tetapi semua itu dapat tertutupi sejak ditariknya kebijakan pemerintah terkait WFH". Adapun jumlah karywan pada Abadi Hotel berjumlah 20 orang karyawan. GM Abadi Hotel juga menambahkan bahwa "sejak terjadinya covid-19 bermacam strategi marketing hotel sudah mereka jalankan baik mulai dengan peningkatan kualitas layanan dengan menggunakan standar protokol kesehatan sangat berdampak terhadap kunjungan hotel dimana sejak berhentinya pemberlakukan WFH jumlah kunjungan hotel meningkat dibandingkan dengan jumah kunjungan hotel setiap bulan disaat sebelum terjadinya pandemic covid-19 hal ini tertentunya dapat membantu dalam menjalankan opersional hotel dan menutupi defisit dari pandapatan hotel disaat diberlakukannya WFH". Hal ini sejalan dengan survey yang dilakukan oleh perhimpunan hotel dan restaurant Indonesia yang menyatakan bahwa Mayoritas hotel berpendapat bahwa kinerja tingkat hunian kamar akan mengalami penurunan sekitar $25-50 \%$ pada awal semester di tahun 2020 dibandingkan awal semester di tahun 2019. Dimana sekitar 25\% responden dari 
total 100\% reponden berpendapat bahwa penurunan semester awal 2020 ini akan mencapai lebih dari 50\% dibandingkan dengan semester awal 2019. Hal ini membuktikan bahwa dari sisi pariwisata khususnya perhotelan lebih mengalami tekanan yang signifikan dari sisi tingkat hunian kamar dibandingkan dengan rata-rata harga kamar, dimana dalam hal ini disarankan bagi pengusaha yang bergerk dibidang perhotelan untuk menurunkan harga kamar untuk menstimulus tambahan jumlah kamar yang terjual selama pandemi virus ini masih berlangsung dengan demikian operasioan hotel sedikit tidak dapat berjalan untuk kelansungan kedepannya. Bagi Abadi Hotel, pendapatan memegang peranan penting dalam menentukan jalannya operasional hotel itu sendiri. Dimana dengan adanya pendapatan yang baik, operasional kegiatan dari hotel dapat berjalan dengan baik pula terlebih untuk pengembangan kedepannya demi mencapai tujuan pemasaran serta untuk mencapai tujuan hotel dalam menciptakan image hotel yang positif serta membangun mutual understanding, goodwill terhadap publik eksternal dan publik internal Abadi Hotel. Jika dilihat dari sisi marketing dimana marketing berfungsi sebagai public relation/humas dalam industri perhotelan dinyatakan sebagai suatu kegiatan komunikasi untuk mengembangkan citra yang baik, meningkatkan kredibilitas hotel, serta meningkatkan tingkat kepercayaan pelanggan hotel dengan cara membuat evaluasi dan menganalisis terkait pendapat pelanggan hotel khususnya yang berhubungan dengan layanan yang diberikan oleh pihak hotel, memberi masukan dan usul cara menangani pendapat, opini atau kritik yang ditujukan pada hotel, mempengaruhi pelanggan hotel melalui teknik komunikasi yang baik sehingga dapat meningkatkan image hotel yang lebih baik.

\section{KESIMPULAN}

Berdasarkan hasil observasi lapangan, penelitian dan pembahasan, maka dapat disimpulkan bahwa pada triwulan pertama sejak pandemi covid-19 menghantam Indonesia pada umumnya dan Lombok pada khusunya sangat berdampak terhadap operasioanl Abadi Hotel, akan tetapi sejak diberhentikannya Work From Home (WFH) tingkat kunjungan hotel mulai membaik dan terlihat ada peningkatan jumlah kunjungan dibandingkan bulan-bulan sebelum pandemic 19 mulai mewabah hal ini berdampak langsung dari sisi pendapatan hotel itu sendiri. Penerapan protocol kesehatan pada hotel merupakan salah satu cara didalam mempertahankan loyality konsumen.

\section{Saran}

Berdasarkan hasil observasi lapangan, penelitian dan pembahasaan peneliti dapat memberikan saran sebagai berikut:

1. Penerapan protocol kesehatan harus dimuali dari kesadaran individu masingmasing agar pandemic ini segera berakhir.

2. Dalam hal marketing mix perlu ditingkatkan disamping tetap mempertahankan customer relationship agar lolality konsumen tetap terjaga disaat pandemic ini masih berlangsung sehingga dapat meningkatkan kunjungan tamu hotel.

3. Bagi peneliti selanjutnya dapat melakukan penelitian tentang pendapatan hotel khusunya pada hotel kelas melati karena disetiap daerah memiliki perbedaan pendapatan terkait implikasi covidterhadap pendapatan hotel terutama hotel kelas melati

\section{DAFTAR PUSTAKA}


Afifudin, H., \& Saebani, B. A. 2009. Metodologi Penelitian Kualitatif, Bandung:CV. Pustaka Setia.

Agus Sulastiyono.1999. Manajemen Penyelenggaraan Hotel.Bandung:Alfabeta

Damanik, Janianton dan Weber, Helmut.2006. Perencanaan Ekowisata Dari Teori Ke Aplikasi. Yogyakarta: PUSPAR UGM dan Andi

Fess,Reeve,Warren.2005. Pengantar Akuntansi.Jakarta : Salemba Empat

Sugiyono.2013.Metode Penelitian Bisnis.Bandung:Alfabeta

Sugiyono.2009.Metode Penelitian Kuantitatif, Kualitatif, dan R \&D .Bandung: Alfabeta

Suwardjono.2008.Teori Akuntansi: Perekayasaan Pelaporan Keuangan.Yogyakarta : BPFE

Undang-Undang Republik Indonesia No.10 Tahun 2009 Tentang Kepariwisataan.

Wiyasha.I.B.M.2010. Akuntansi Perhotelan.Yogyakarta :Andi Offset

Yin, R. K. 2002. Studi Kasus Desain dan Metode, Terjemahan, M. D. Mudzakir, Jakarta: PT RajaGrafindo Persada.

Yoeti,Oka A.2008.Perencanaan Dan Pengembangan Pariwisata. Jakarta

Website:

https://id.wikipedia.org/wiki/Pandemi_koonavirus_di_Indonesia

www.majalahpendidikan.com

www.majalahpendidikan.com

www.pariwisata dan teknologi.blogspot.com

www.rafans detik.blogdetik.com 